\title{
LETTER
}

\section{Trace and rare earth element geochemistry of clinopyroxene in mafic dykes from Western Dharwar craton, southern India}

\author{
Sasidharan A. Silpa ${ }^{*}$, M. SATISH-Kumar ${ }^{*}$, Eiichi TAKAZAWA ${ }^{*}$ and Krishnan SAJEev ${ }^{* *}$ \\ ${ }^{*}$ Department of Geology, Faculty of Science, Niigata University, Niigata 950-2181, Japan \\ ${ }^{* *}$ Centre for Earth Sciences (CEaS), Indian Institute of Science, Bangalore 560 012, India
}

\begin{abstract}
The major and trace element characteristics of the clinopyroxene from two generations of dykes, dolerite and olivine dolerite dykes of Western Dharwar Craton were investigated by using electron microprobe and LAICPMS. The clinopyroxene in dolerite dykes show a compositional zoning with $\mathrm{Mg} \#$ decreasing from the core to the rim ( 85 to 51 ) and $\mathrm{Cr}_{2} \mathrm{O}_{3}$ contents decrease towards the rim. The trace and rare earth element (REE) pattern of the core shows lower concentrations of REEs compared to the rim. The clinopyroxene in the olivine dolerites are devoid of zoning and compositionally more primitive than the dolerites as visible in the trace element and REE concentrations. The dolerite and olivine dolerite are formed from different source magmas and the fractional crystallization of clinopyroxene is dominant in dolerites. The present estimated melt composition in equilibrium with clinopyroxene is consistent with the bulk rock composition for dolerite and olivine dolerite.
\end{abstract}

Keywords: LA-ICPMS, clinopyroxene, dolerite dykes, Western Dharwar craton

\section{INTRODUCTION}

The Late Archean to Early Proterozoic mafic dyke swarms of the Western Dharwar craton (WDC) are significant as they are windows for understanding the nature and composition of subcontinental lithospheric mantle (SCLM). They provide critical information regarding the mantle dynamics during the Late Archean to Early Proterozoic and helps to understand the tectonic evolution of the Dharwar craton. Major and trace element zoning of the minerals like clinopyroxenes from these mantle-derived rocks are indicators of magmatic processes such as the extent of melt extraction from the mantle, followed by fractional crystallization and/or magma mixing and through to the assimilation during emplacement at crustal depths (Griffin et al., 1996; Natland and Dick, 1996, 2001; Blundy and Wood, 2003). Furthermore, the REE concentrations help to identify the origin and evolution of the SCLM beneath the Dharwar craton.

This study evaluates the compositional variation and geochemical characteristics of clinopyroxene from dolerite and olivine dolerite dykes from the Western Dharwar craton to understand the formation and evolution of these dykes.

\section{BACKGROUND}

The Western Dharwar craton in Southern India is the oldest and the thickest part of the Archean Dharwar craton that is mainly composed of the $4.0-2.56 \mathrm{Ga}$ tonalitetrondhjemite-granodiorite (TTG) gneisses, the 3.35-3.20 Ga and 2.90-2.54 Ga greenstone belts, and 2.62-2.52 Ga calc-alkaline to potassic granites (Radhakrishna and Naqvi, 1986; Rao et al., 1991; Dey, 2013; Jayananda et al., 2018). The entire craton is intruded by Late Archean to Early Proterozoic mafic dykes of varying dimensions and compositions (Fig. 1). The dykes in the WDC are classified into two main categories based on their lithological and geochemical characteristics as younger dolerite dykes and older meta-dolerite dykes (Silpa and SatishKumar, 2018; Rai et al., 2019). The current report deals with the unmetamorphosed dolerite dykes in WDC that preserves ophitic and poikilitic textures and pristine mineralogical characteristics. Those with the ophitic texture, composed of lath shaped plagioclase and clinopyroxenes are referred to hereafter as dolerites, whereas those with a poikilitic texture and are composed of olivine, clinopyroxene and plagioclase are referred to as olivine dolerites. 

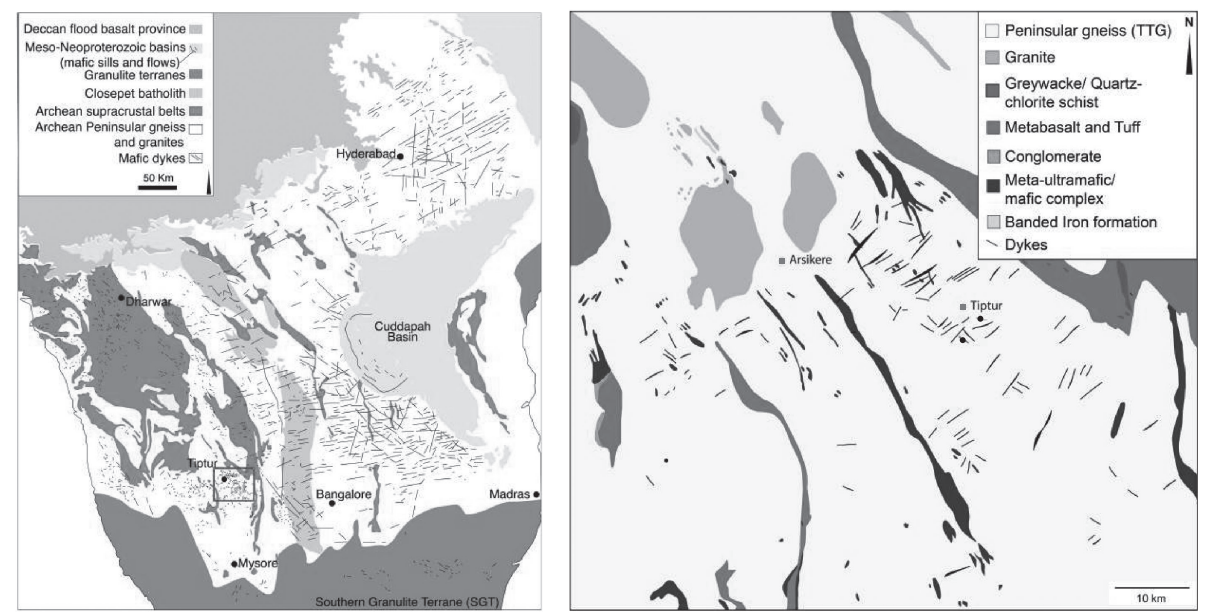

Figure 1. Simplified geologic map of Dharwar craton showing the distribution of mafic dykes (left) (modified after French and Heaman, 2010). The enlarged map of study area (right). Sampling localities of dolerite and olivine dolerite in this study are marked as solid circles. Color version is available online from https://doi.org/10.2465/jmps. 201130c.

\section{SAMPLING AND ANALYTICAL METHODS}

Detailed sampling of the dykes that commonly trend NESW and NW-SE has been carried out, and samples were collected from the central part of the dyke to avoid any possible contamination. Most of the dykes were massive, and relationship with the country-rock could not be identified in the field; however, the linear trends of the dykes are visible from the elongated resistant hillocks compared to the flat planar topography of the surrounding TTG gneisses. Systematic petrographic investigations were carried out on polished thin sections and areas where pristine clinopyroxene grains were demarcated for JEOL JXA-8230 electron probe micro analysis (EPMA) in the Advanced Facility for Microscopy and Microanalysis (AFFM) at Indian Institute of Science (IISc), Bangalore. Back-scattered electron (BSE) images were taken before the analysis to identify the minerals present as well as the textures. The LA-ICPMS (laser ablation inductively coupled plasma mass spectrometry) analysis of clinopyroxene was carried out with the Agilent 7500a ICP-MS facility housed at the Faculty of Science, Niigata University. Nd: YAG (neodymium doped yttrium aluminum garnet crystal) laser system (New Wave Research UP-213) was used for the current analysis. Analytical conditions include helium as the carrier gas with a flow rate of 1.25 $1 / \mathrm{min}$, the laser spot size of $80 \mu \mathrm{m}$ with an energy density of approximately $12 \mathrm{~J} / \mathrm{cm}^{2}$ and laser repetition rate of 4 Hz. Core and rim points were separately measured to understand the difference in the composition. Concentration of standard reference material NIST-SRM 610 glass is used for primary calibration.

\section{RESULTS}

The dolerite dykes are undeformed and is characterized by euhedral to subhedral minerals with well-preserved igneous textures. Dolerites show typical ophitic texture with subhedral clinopyroxene and plagioclase laths. Olivine dolerites appear fresh under thin section observation and are composed of plagioclase, clinopyroxene, and olivine with a very few orthopyroxene grains (Figs. $2 a$ and $2 b$ ). The BSE images of the clinopyroxene in dolerite show a darker core and a lighter rim indicating a compositional zoning. (Fig. 2c). The olivine dolerites do not show continuous compositional zoning like dolerites although there are variations within the core of the clinopyroxene grain (Fig. 2d).

The variations seen in the BSE images are reflected in the elemental concentrations as well. Major oxide $\mathrm{SiO}_{2}$ doesn't show any significant variation with the concentration ranging between 49.3 and $56.1 \mathrm{wt} \% . \mathrm{MgO}$ on the other

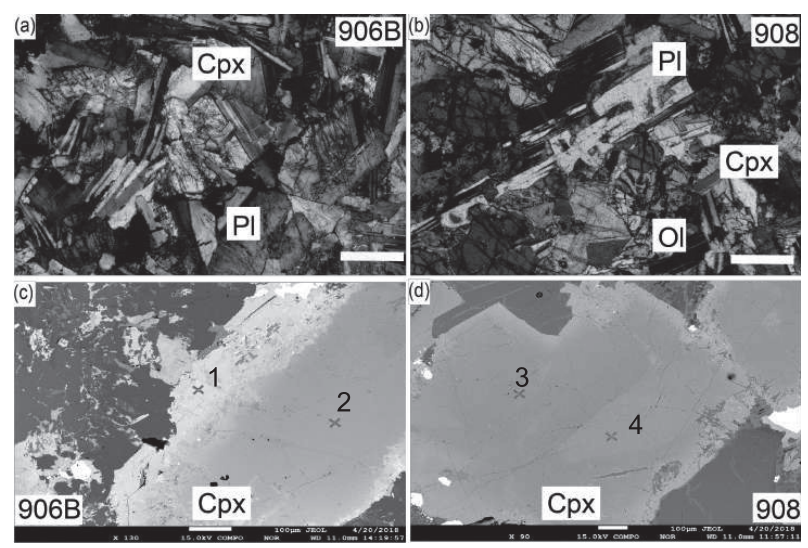

Figure 2. Photomicrographs (crossed nicols) of dolerites (a) showing ophitic texture and olivine dolerite (b) showing poikilitic textures. The scale is $0.2 \mathrm{~mm}$. Back-scattered electron images showing the compositional zoning of the clinopyroxene as observed in dolerite (c) olivine dolerite (d). LA-ICPMS analytical points are marked. Color version is available online from https://doi.org/ 10.2465/jmps.201130c. 
hand shows more considerable variations ranging from a high value of 27.9 to the least of $8.8 \mathrm{wt} \%$ coinciding with the compositional zoning. Other major oxides like $\mathrm{CaO}$ and $\mathrm{FeO}$ show a range of 11.2-19.3 and 5.3-25.9 $\mathrm{wt} \%$, respectively. $\mathrm{Cr}_{2} \mathrm{O}_{3}$ for dolerite ranges from 0.58 in the core to $0.01 \mathrm{wt} \%$ towards the rim. The $\mathrm{Mg} \#$ is found to be the highest at the core and the least at the rim for the clinopyroxene in dolerites, whereas in olivine dolerites they don't show compositional differences within the grain. Core to rim compositional variation of the clinopyroxene in dolerite is reflected in the REE concentrations as well. The average La concentration for the core is $0.35 \mathrm{ppm}$, and the rim is $0.83 \mathrm{ppm}$, whereas for the clinopyroxene in olivine dolerite it is $0.42 \mathrm{ppm}$. For heavy rare earths a similar trend in concentration is noticeable (Table 1).

\section{DISCUSSION}

The dolerite and olivine dolerites preserve pristine magmatic crystallization textures, and the zoning within the clinopyroxene grains are primary. The primary zoning can result either due to the modification of the parent melt composition during crystal growth or due to the variations in crystallizing conditions (Tracy, 1982; Loomis, 1983). The composition of clinopyroxene in dolerite shows significant differences in $\mathrm{Cr}$ concentrations within a single grain. The core is having higher concentrations than the rim. There is also a concomitant decrease in $\mathrm{Mg} \#$ from the core to the rim. The discrimination diagrams of $\mathrm{Mg} \#$ versus $\mathrm{Cr}_{2} \mathrm{O}_{3}$ indicates a significant positive correlation although the concentrations are different for the clinopyroxene in dolerite and olivine dolerite (Figs. $3 a$ and $3 b$ ). It can be assumed that the core is in equilibrium with original parental melt, and the zoning is possibly indicating the compositions that are in equilibrium with the decreasing temperature conditions during its crystallization. The pyroxene compositions were plotted in a quadrilateral with isotherms from Lindsley (1983), which helped to constrain the temperature conditions of clinopyroxene crystallization. The dolerites are showing a wide temperature range of $1200-900{ }^{\circ} \mathrm{C}$ with the core compositions falling on the higher temperature side whereas the olivine dolerites are showing a limited distribution with temperatures ranging from 1200 to $1000{ }^{\circ} \mathrm{C}$ (Fig. 3c).

The REE concentrations of dolerite are enriched towards the rim of the clinopyroxene. Primitive mantlenormalized (Figs. 4a and 4b) and chondrite-normalized REE patterns (Figs. 4c and 4d) for both dolerites and olivine dolerites show depletion in LILE and a nominal enrichment of REE with a negative anomaly for $\mathrm{Li}$ and $\mathrm{Zr}$ with olivine dolerite being slightly depleted. In the chondrite-normalized REE patterns for dolerites, the
Table 1. Mineral composition of representative clinopyroxene in dolerite and olivine dolerite dykes

\begin{tabular}{|c|c|c|c|c|}
\hline & \multicolumn{2}{|c|}{ Dolerite } & \multicolumn{2}{|c|}{ Olivine dolerite } \\
\hline & 906B-1 (rim) & 906B-2 (core) & $908-3$ & $908-4$ \\
\hline \multicolumn{5}{|c|}{ Major oxides concentration from EPMA } \\
\hline $\mathrm{SiO}_{2}$ & 53.16 & 52.66 & 52.71 & 52.54 \\
\hline $\mathrm{TiO}_{2}$ & 0.15 & 0.14 & 0.15 & 0.31 \\
\hline $\mathrm{Al}_{2} \mathrm{O}_{3}$ & 2.42 & 1.54 & 3.02 & 3.05 \\
\hline $\mathrm{Cr}_{2} \mathrm{O}_{3}$ & 0.007 & 0.538 & 0.787 & 0.229 \\
\hline $\mathrm{FeO}$ & 7.06 & 16.48 & 5.45 & 8.85 \\
\hline $\mathrm{MnO}$ & 0.15 & 0.31 & 0.21 & 0.29 \\
\hline $\mathrm{MgO}$ & 17.81 & 20.07 & 17.63 & 17.37 \\
\hline $\mathrm{CaO}$ & 18.50 & 8.10 & 19.14 & 16.14 \\
\hline $\mathrm{Na}_{2} \mathrm{O}$ & 0.12 & 0.13 & 0.15 & 0.23 \\
\hline $\mathrm{K}_{2} \mathrm{O}$ & 0.002 & 0.010 & 0.013 & 0.142 \\
\hline Total & 99.90 & 99.44 & 99.25 & 99.16 \\
\hline \multicolumn{5}{|c|}{ Trace and rare earth element concentrations from LA-ICPMS } \\
\hline $\mathrm{Li}$ & 1.8 & 10.5 & 6.4 & 5.9 \\
\hline Sc & 31 & 117 & 59 & 82 \\
\hline V & 88 & 380 & 136 & 192 \\
\hline Co & 41 & 145 & 44 & 38 \\
\hline $\mathrm{Zn}$ & 27 & 171 & 22 & 19 \\
\hline $\mathrm{Ga}$ & 1.37 & 6.41 & 2.18 & 3.05 \\
\hline $\mathrm{Rb}$ & 0.04 & 5.02 & 0.01 & 0.04 \\
\hline $\mathrm{Sr}$ & 4.27 & 17.27 & 5.10 & 7.16 \\
\hline $\mathrm{Y}$ & 3.26 & 20.44 & 5.85 & 8.20 \\
\hline $\mathrm{Zr}$ & 1.82 & 22.79 & 2.10 & 4.32 \\
\hline $\mathrm{Nb}$ & 0.00 & 0.19 & 0.01 & 0.02 \\
\hline Cs & 0.00 & 0.49 & 0.01 & 0.01 \\
\hline $\mathrm{Ba}$ & 0.1 & 6.9 & 0.9 & 0.1 \\
\hline $\mathrm{La}$ & 0.37 & 2.31 & 0.19 & 0.33 \\
\hline $\mathrm{Ce}$ & 0.92 & 5.36 & 0.62 & 1.13 \\
\hline $\operatorname{Pr}$ & 0.20 & 1.08 & 0.13 & 0.26 \\
\hline $\mathrm{Nd}$ & 1.1 & 6.7 & 0.9 & 1.7 \\
\hline $\mathrm{Sm}$ & 0.36 & 2.60 & 0.34 & 0.56 \\
\hline $\mathrm{Eu}$ & 0.140 & 0.766 & 0.195 & 0.237 \\
\hline $\mathrm{Gd}$ & 0.45 & 3.48 & 0.60 & 1.09 \\
\hline $\mathrm{Tb}$ & 0.095 & 0.669 & 0.149 & 0.202 \\
\hline Dy & 0.68 & 3.75 & 1.05 & 1.58 \\
\hline Ho & 0.130 & 0.877 & 0.248 & 0.307 \\
\hline Er & 0.41 & 2.32 & 0.69 & 0.78 \\
\hline $\mathrm{Tm}$ & 0.07 & 0.33 & 0.10 & 0.11 \\
\hline $\mathrm{Yb}$ & 0.38 & 2.12 & 0.57 & 0.75 \\
\hline $\mathrm{Lu}$ & 0.051 & 0.297 & 0.076 & 0.138 \\
\hline $\mathrm{Hf}$ & 0.11 & 0.93 & 0.11 & 0.34 \\
\hline $\mathrm{Ta}$ & 0.002 & 0.025 & 0.005 & 0.002 \\
\hline $\mathrm{Pb}$ & 0.03 & 0.54 & 0.07 & 0.04 \\
\hline Th & 0.004 & 0.195 & 0.002 & 0.000 \\
\hline $\mathrm{U}$ & 0.002 & 0.042 & 0.004 & -0.002 \\
\hline
\end{tabular}

smoothly changing concentrations indicate that a source variation in magma is not involved. The REEs patterns for olivine dolerites have a depletion of light REEs with a slight Eu negative anomaly (Figs. 4c and 4d). 

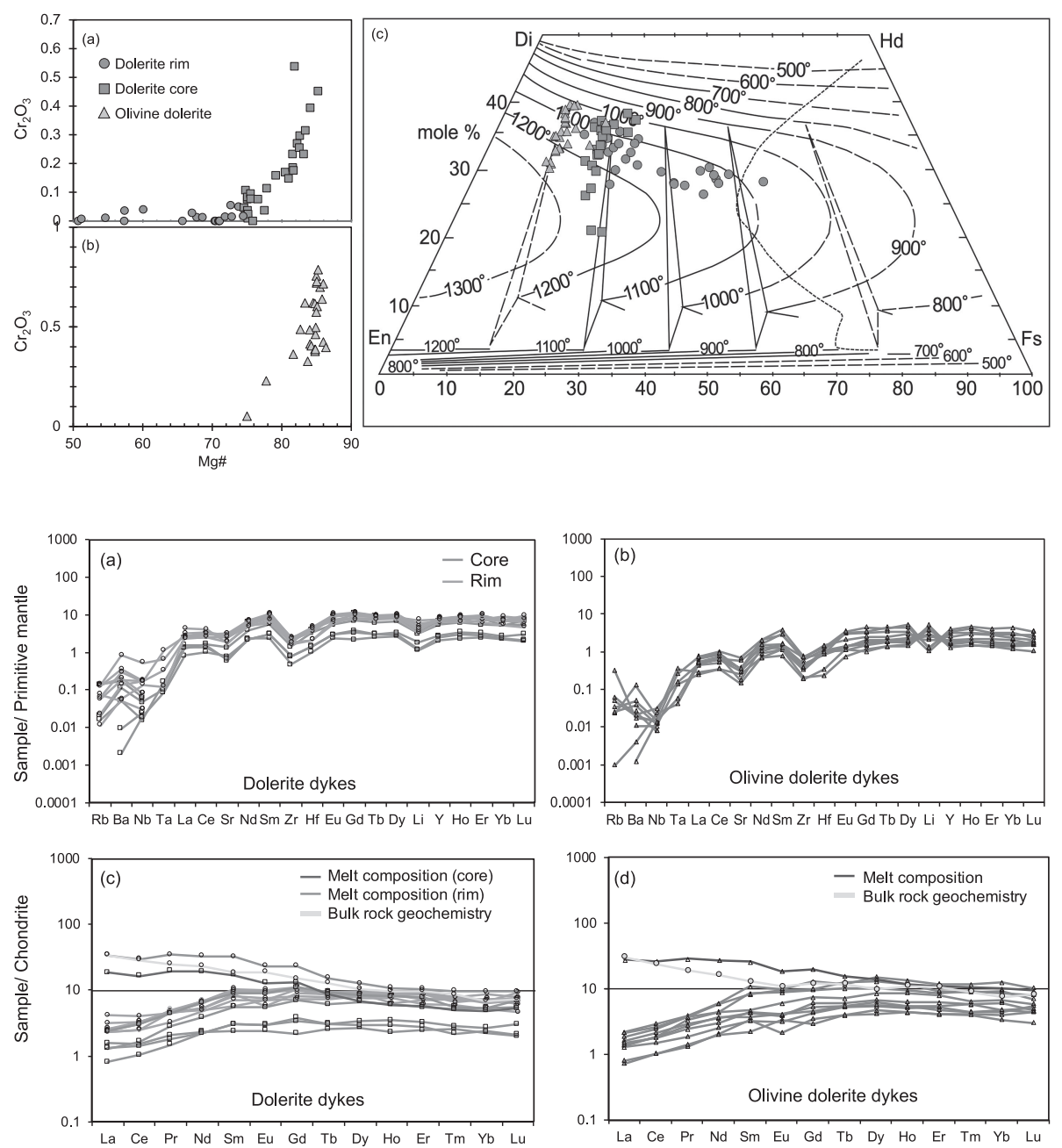

Figure 3. Discrimination diagrams of $\mathrm{Mg} \#$ versus $\mathrm{Cr}_{2} \mathrm{O}_{3}$ for clinopyroxene mineral (a) dolerite is showing high $\mathrm{Mg} \#$ and high $\mathrm{Cr}_{2} \mathrm{O}_{3}$ in the core compared to the rim, positive correlation can be seen (b) olivine dolerite showing high $\mathrm{Mg} \#$ and more or less clustered distribution. (c) Clinopyroxene quadrilateral showing the compositional distribution and isotherm are after Lindsley (1983). Color version is available online from https://doi.org/10.2465/ jmps.201130c.

Figure 4. Primitive mantle normalized pattern for the clinopyroxene for (a) dolerites (b) olivine dolerites, Chondrite normalized REEs pattern for clinopyroxene for (c) dolerites (d) olivine dolerites. Chondrite normalized REEs pattern for the estimated melt composition in equilibrium with clinopyroxene for dolerite and olivine dolerite is shown in (c) and (d). For dolerite, average core values and average rim values were taken for calculation. REE pattern for the melt in equilibrium with clinopyroxene for both dolerite and olivine dolerite is compared with bulk rock geochemistry. Normalizing values from McDonough and Sun (1995). Bulk rock compositions are after Silpa et al. (2021). Color version is available online from https://doi.org/10.2465/jmps. 201130c.
Using the partition coefficients, it is possible to estimate the composition of melt in equilibrium with that particular phase. Considering the clinopyroxene as the major crystallizing phase in the dolerites, the composition of melt in equilibrium with clinopyroxene was estimated using the partition coefficients reported by Laubier et al. (2014) and Salters et al. (2002). The average values of core and rim compositions of the dolerites and the average composition of the olivine dolerite have been used separately for the calculation. The estimated melt composition for both the dolerite and olivine dolerite was found to be consistent with the bulk rock geochemistry as reported in Silpa et al. (2021). However, the bulk rock composition of the middle rare earths is showing a more depleted nature as compared to the estimated melt in equilibrium with clinopyroxene (Figs. 4c and 4d). This can happen if the early formed nuclei do not re-equilibrate with the surrounding melt as in the case of an in- situ crystallization (Langmuir, 1989). A likely scenario is that the clinopyroxene crystallized at an early stage before plagioclase while deviating from equilibrium with the residual melt. Further detailed grain-scale analysis of clinopyroxene and co-existing phases are necessary to investigate this in detail.

The study of mafic dykes in WDC is thought to provide significant information regarding the nature and evolution of SCLM beneath the DC and the mantle dynamics in Precambrian. The source of the olivine dolerites in the present study is considered to be the primitive mantle material based on the bulk rock and $\mathrm{Sr}-\mathrm{Nd}$ isotope geochemical characteristics (Silpa et al., 2021) that has crystallized under uniform physical conditions without any mixing of other sources, including crustal assimilation. In the case of dolerite, the $\mathrm{Cr}$-rich core in the clinopyroxene preserves the original melt composition and the trace elements and REE compositions with $\mathrm{Sr}, \mathrm{Nb}$, and $\mathrm{Pb}$ 
anomalies are indicative of the influence of subducted materials on the mantle source. However, the gradual enrichment seen in the overall trace and REE characteristics from the core to the rim and the wide range of temperature of crystallization seen in the clinopyroxene thermometry leads to the possible explanation that the compositional zoning is a result of the magmatic differentiation. The crystallization of core occurred at a higher temperature, possibly at a deeper magma reservoir, whereas the rim crystallized at a lower temperature. Therefore, the possibility of a magma mixing can be negated. Since the rim of the clinopyroxene in olivine dolerite does not show compositional variation, it is possible that the olivine dolerite magma cooled more rapidly than dolerite. Further detailed studies on the compositional variations, including $\mathrm{Sr}-\mathrm{Nd}$ isotopic composition recorded in clinopyroxene are necessary to substantiate the subcontinental lithospheric mantle evolution of the Dharwar craton in the Late Archean to Early Proterozoic.

\section{ACKNOWLEDGMENTS}

This work was supported by the scholarship of Ministry of Education, Culture, Sports, Science and Technology (MEXT), Japan to S.A.S. and was supported by MEXT KAKENHI Grant Number JP15H05831 to MS-K.

\section{SUPPLEMENTARY MATERIAL}

Color version of Figures 1-4 is available online from https://doi.org/10.2465/jmps.201130c.

\section{REFERENCES}

Blundy, J. and Wood, B. (2003) Partitioning of trace elements between crystals and melts. Earth and Planetary Science Letters, 210, 383-397.

Dey, S. (2013) Evolution of Archaean crust in the Dharwar craton: the Nd isotope record. Precambrian Research, 227, 227-246.

French, J.E. and Heaman, L.M. (2010) Precise U-Pb dating of Paleoproterozoic mafic dyke swarms of the Dharwar craton, India: implications for the existence of the Neoarchean supercraton Sclavia. Precambrian Research, 183, 416-441.

Griffin, W.L., Smith, D., Ryan, C.G., O'Reilly, S.Y. and Win, T.T. (1996) Trace-element zoning in mantle minerals: metasomatism and thermal events in the upper mantle. Canadian Mineralogist, 34, 1179-1193.

Jayananda, M., Santosh, M. and Aadhiseshan, K.R. (2018) Formation of Archean (3600-2500 Ma) continental crust in the Dharwar Craton, southern India. Earth-Science Reviews, 181, 12-42.

Langmuir, C.H. (1989) Geochemical consequences of in situ crys- tallization. Nature, 340, 199-205.

Laubier, M., Grove, T.L. and Langmuir, C.H. (2014) Trace element mineral/melt partitioning for basaltic and basaltic andesitic melts: An experimental and laser ICPMS study with application to the oxidation state of mantle source regions. Earth and Planetary Science Letters, 392, 265-278.

Lindsley, D.H. (1983) Pyroxene thermometry. American Mineralogist, 68, 477-493.

Loomis, T.P. (1983) Compositional zoning of crystals: a record of growth and reaction history. In Advances in physical geochemistry (Saxena SK Ed.). Springer, Berlin Heidelberg New York. $1-60$.

McDonough, W.F. and Sun, S.S. (1995) The composition of the Earth. Chemical Geology, 120, 223-253.

Natland, J.H. and Dick, H.J. (1996) Melt migration through highlevel gabbroic cumulates of the East Pacific Rise at Hess Deep: the origin of magma lenses and the deep crustal structure of fast-spreading ridges. In Proceedings- Ocean Drilling Program Scientific Results. National Science Foundation. 21-58.

Natland, J.H. and Dick, H.J. (2001) Formation of the lower ocean crust and the crystallization of gabbroic cumulates at a very slowly spreading ridge. Journal of Volcanological and Geothermal Research, 110, 191-233.

Radhakrishna, B.P. and Naqvi, S.M. (1986) Precambrian continental crust of India and its evolution. Journal of Geology, 94,145166.

Rai, A.K., Srivastava, R.K., Samal, A.K. and Sesha Sai, V.V. (2019) Geochemistry, petrogenesis, and geodynamic implications of NE-SW to ENE-WSW trending Paleoproterozoic mafic dyke swarms from southern region of the western Dharwar Craton. Geological Journal, 54, 2847-2869.

Rao, Y.B., Naha, K., Srinivasan, R. and Gopalan, K. (1991) Geology, geochemistry and geochronology of the Archaean Peninsular gneiss around Gorur, Hassan district, Karnataka, India. Proceedings of the Indian Academy of Sciences-Earth and Planetary Sciences, 100, 399-412.

Salters, V.J., Longhi, J.E. and Bizimis, M. (2002) Near mantle solidus trace element partitioning at pressures up to 3.4 GPa. Geochemistry, Geophysics, Geosystems, 3, 10.1029/ $2001 \mathrm{GC} 000148$.

Silpa, A.S. and Satish-Kumar, M. (2018) Dyke swarms in the Dharwar craton: A key to understanding the Late Archean to Early Proterozoic cratonic correlations. Journal of the Indian Institute of Science, 98, 365-378.

Silpa, A.S., Satish-Kumar, M. and Takahashi, T. (2021) Sr-Nd isotopic study of dolerite dykes in the Western Dharwar craton, southern India: Implications for the evolution of the subcontinental lithospheric mantle in late Archean. Lithos. doi: 10. 1016/j.lithos.2021.106023.

Tracy, R.J. (1982) Compositional zoning and inclusions in metamorphic minerals. In Characterization of metamorphism through mineral. Characterization of metamorphism through mineral equilibria (Ferry, J.M. Ed.). Reviews in Mineralogy and Geochemistry, 10, 355-397.

Manuscript received November 30, 2020

Manuscript accepted March 29, 2021

Published online April 27, 2021

Manuscript handled by Toshiaki Tsunogae 